\title{
The presence of YHWH in exile according to the Book of Ezekiel, with special reference to the meaning of the expression מִקְָָּש מְעַט in Ezekiel 11:16
}

\author{
Pieter De Vries (VRiJe Universiteit, AmsterdaM)
}

\begin{abstract}
In Ezek 11:16, we find the promise that YHWH will be for the people

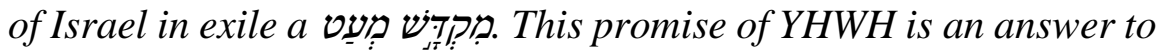
the desperate exclamation of the prophet: "Ah, Lord God! Will you make a full end of the remnant of Israel?" (Ezek 11:13b). ${ }^{1}$ In this article, I investigate not only whether we must understand this expression as "a little sanctuary" or "a sanctuary for a while", but also in what sense we must understand the presence of YHWH among the exiles in the form of a sanctuary.
\end{abstract}

Ezekiel was the only Hebrew prophet mentioned in the HB to receive his calling in exile. The kernel of his message was that hope for Israel would exclusively be realized through the exilic community. The readers of his book are urged to distance themselves from the past and orientate themselves on the future. In his second vision, the prophet sees the glory of YHWH depart the temple. This is the very time at which he receives the promise for the exilic community that

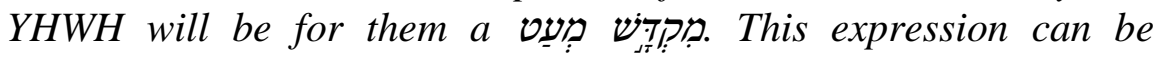
understood both as a small and a temporal sanctuary.

In exile, both the prophet himself and the oracles of hope he receives mediate the presence of $\mathrm{YHWH}$ for the exilic community. Hence, we can say that the message of the prophet Ezekiel is the

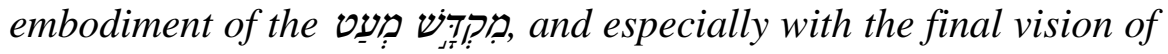
the return of the glory of YHWH to a completely new and purified temple, Ezekiel the prophet functions as a priest. This vision gives hope to the exiles in their present condition. It also makes clear that

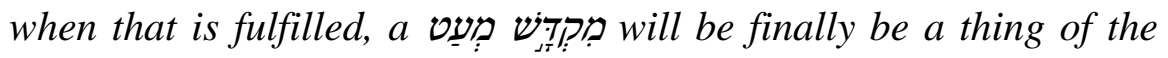
past. The temporary character of the מדקרָּ will then definitely have elapsed, and the presence of $Y H W H$ will no longer be a reduced presence.

* Submitted: 19/09/2017; peer-reviewed: 24/12/2017; accepted: 12/02/2018. Pieter de Vries, "The presence of YHWH in exile according to the Book of Ezekiel, with special reference to the meaning of the expression no. 1 (2018): 264-279. DOI: https://doi.org/10.17159/2312-3621/2018/v31n1a13

1 The English translation I follow is the ESV. 


\section{A INTRODUCTION}

No event before the Common Era had such a disrupting effect on the people of Israel as the destruction of Jerusalem with its temple of YHWH. A great number of the people who survived the destruction were deported to Babylon. ${ }^{2}$ Even before the destruction of Jerusalem, a substantial part of the upper classes had already gone into exile.

What was the cause of the exile? Why did YHWH not prevent the destruction of Jerusalem and the temple? Was there any future for the people of Israel? And if the answer to the latter was affirmative, could anything concretely be said about this future? Such were the questions with which the people of Israel wrestled in exile.

We feel the impact of the exile in much of the HB or the OT: either as something foreseen, a present or a past reality. As a foreseen and present reality, this is especially true of the Major Prophets Isaiah, Jeremiah and Ezekiel. The HB interprets the Babylonian exile as the fulfilment of prior promises of judgment and blessing. We may mention especially in this regard the curses and blessings of the Holiness Code in Leviticus and in Deuteronomy. ${ }^{3}$ Instead of ending with judgement, however, all the prophetic books culminate in hope and joyful expectation. That hope is expressed in language which makes increasingly

2 I do not enter here into the discussion as to what the percentage of the people who remained in the land had been. Certainly, a substantial number remained, as indicated by archaeological data. A close reading shows us that this is not in contradiction to the HB. Cf. Kenneth A. Kitchen, On the Reliability of the Old Testament (Grand Rapids: Eerdmans, 2003), 67: "The idea that the Babylonians carried everybody from both Jerusalem and Judah off to Babylon is true neither archaeologically nor to the biblical text itself." However, the HB or OT represents with regard to the exile almost exclusively the viewpoint of the exiles and not of the people who remained in the land. From the perspective of the exiles, a theological explanation is given of the destruction of Jerusalem and the first temple. The book of Lamentations is a notable exception, but the explanation given there is the same as in other texts of the HB. Lamentations most likely reflects the feelings of people who survived the Babylonian siege and remained in the land.

3 Especially in the book of Ezekiel, we see a close relationship between the prophecies of Ezekiel and the Holiness Code. Margaret S. Odell, Ezekiel, SHBC (Macon: Smyth \& Helwys Publishing, 2005), 162, 284, 291, 487, 488; Michael A. Lyons, From Law to Prophecy: Ezekiel's Use of the Holiness Code, LHBOTS 507 (New York: T \& T Clark, 2009); Pieter de Vries, The Kābôd of Yhwh in the Old Testament: With Particular Reference to the Book of Ezekiel, SSN 65 (Leiden: Brill, 2015), $262 \mathrm{ff}$. 
plain that the future reality would far surpass whatever had been seen heretofore. ${ }^{4}$ This is especially true of Ezekiel.

More than Isaiah and his near contemporary Jeremiah, Ezekiel must be characterized as a prophet of the exile. He is the only of the Scripture prophets who was called to his office in the Babylonian exile; an exile that according to the view represented in the book of Ezekiel had started already with the deportation of king Jehoiakchin and a section of the elite of Jerusalem in 598/597 BCE.

What is true of the person of Ezekiel is also true of the book that bears his name. The whole book is structured from the viewpoint of the reality and cause of the exile and its reversal. YHWH is portrayed as the sole performer both of the exile and its reversal. The exile was not caused because Babylon or its gods were mightier than YHWH, but rather its cause was the sin of the people of Israel. ${ }^{5}$ Idolatry, social and sexual sins and sabbath violation are particularly mentioned in this regard. As a priest who was called by YHWH to be his prophet, Ezekiel prefers cultic terms for describing sin, even when its character is not cultic. $^{6}$

Likewise, when the prophets predict the reversal of the exile, he uses a fair preponderance of cultic terms (see Ezek 36). Ezekiel's final vision of the

4 Ronald E. Clements, "Law and Promise," in Old Testament Theology: Flowering and Future, ed. Ben C. Ollenburger (Winona Lake: Eisenbrauns, 2004), 167.

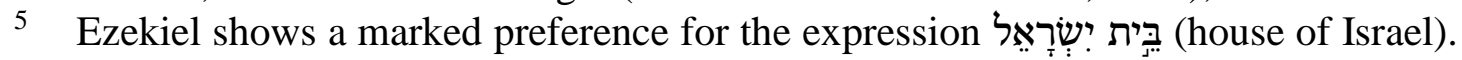
"House of Israel" usually signifies Judah and Jerusalem and its inhabitants, but it also denotes the exilic community. This latter use is an indication of a hopeful future for Israel. "Israel" is used 186 times, "house of Israel" 83 times (out of a total of 147 times in the HB), "Judah" 15 times, and "house of Judah" 5 times. The terms "house of Judah" and "house of Israel" are used in parallel for the citizens of Jerusalem in Ezek 8:6, 1012,17 . The terms "elders of Israel" and "elders of Judah" are used indiscriminately in Ezek 8:1; 20:1, 3 for the leaders of the exilic community. Although in Ezek 9:9; 25:3; 27:17 Israel and Judah are mentioned alongside each other, there is no indication that they refer to two different entities. The only exception to this is Ezek 4:4-6; in the dichotomy described there, "Israel" refers to the northern kingdom and "Judah" to the southern kingdom. In Ezek 37:17, "Judah" is used for the southern kingdom and "Joseph" and "Ephraim" for the northern kingdom. The really important distinction in the book of Ezekiel is that between the community in the homeland and in Babylon. The future belongs to the latter community.

6 When Ezek 1:1 states that the prophet was called in the thirtieth year, I think this is a reference to the prophet's age (his thirtieth year). Ezekiel was called to be a prophet at the age at which if he had been in Jerusalem, he would have been anointed a priest (Num 4:23). Leslie C. Allen, Ezekiel 1-19, WBC 28 (Dallas: Word Books, 1994), 3940; Moshe Greenberg, Ezekiel 1-20, AB 22 (Garden City: Doubleday, 1983), 39; Walther Zimmerli, Ezechiel 1-24, BKAT 13/1 (Neukirchen-Vluyn: Neukirchener Verlag, 1996), 40ff.; de Vries, Kābôd, 237-238. 
return of the glory of YHWH to a new temple and a completely renewed land inhabited by a completely renewed people is the climax of his prophecies, and that not only structurally but also with regard to its content. The reversal of the exile is solely ascribed to YHWH. His only reason for giving Israel a new and glorious future is that he is determined to vindicate his own name. The repentance of the people does not precede but rather follows the gift of the renewing spirit of YHWH to his people.

Even more radically than his near-contemporary Jeremiah, Ezekiel proclaimed in the name of YHWH that fulfilment of the promise of the glorious future would take different forms than many of their contemporaries had imagined. This future was not for the inhabitants of Jerusalem or Judah, either before or after the destruction of Jerusalem, but was for the exiles in Babel and their offspring. ${ }^{7}$ For Ezekiel, the glorious future of Israel is first and foremost a future with the glory of YHWH in its midst.

Noteworthy is that for Ezekiel, the actual exile started not with the destruction of Jerusalem and its temple, but with the deportation of king Jehoiachin. ${ }^{8}$ Ezekiel wrote his book to interpret for the exiles in Babylon the disaster of the exile. His message offered them hope for their future that far surpassed their imagination. ${ }^{9}$ The book itself has its origins completely in exile; ${ }^{10}$ this is another way in which it distinguishes itself from the book of Jeremiah.

7 In the book of Jeremiah, too, we see that YHWH will bring the future of salvation through the means of deportation to Babylon. This is stated explicitly in Jer 24, 27 and 29. The narrative of the assassination of Gedaliah (Jer 41-44) shows that all other ways will come to a dead end. Eric Peels, "The Assassination of Gedaliah (Jer 40:7-41:18)," in Exile and Suffering, ed. Bob Becking and David Human, OtSt 50 (Leiden: Brill, 2009), 99-101.

8 The dates in the book of Ezekiel are given as reckoned from this deportation.

9 The book of Ezekiel is actually about what YHWH told the prophet to say, not what Ezekiel said to the people. More than any of the other prophetic books, the book of Ezekiel was immediately committed to writing. We must assume that the prophet's written compositions were read aloud after delivery. Ezekiel must be seen not only as prophet and priest but also as a writer. His first delivery of much of his message was directly in writing, i.e. there was never a time when his message was free of the written form. It is telling in this connection that he had to eat a scroll when he was first called (Ezek 2:1-3; cf. 24:1-2 and 37:16). Ellen F. Davis, Swallowing the Scroll: Textuality and the Dynamics of Discourse in Ezekiel's Prophecy, JSOTSup 78 (Sheffield: Sheffield University Press, 1989), 45. That does not mean that we have to deny that the written book derives from an oral exchange (Thomas Renz, The Rhetorical Function of the Book of Ezekiel, VTSup 76, Leiden: Brill, 1999), 16.

10 I think this is true of the whole book, the chapter on Gog and the final vision included. I do not deny that we see signs of editing in the book of Ezekiel, but even this editing can be dated to the exile and was perhaps already partly done by the prophet himself. 
Thomas Renz rightly called attention to the strongly rhetorical character that the book of Ezekiel has in the form we have it. Readers are called upon to distance themselves from Israel's past. They are invited to identify themselves with the exilic community at the river Chebar in Babel and to orientate themselves, just as this exilic community was expected to do, radically towards a totally new and brilliant future. ${ }^{11}$

The hope of the future is exclusively ascribed to YHWH and not to possibilities or capacities of the exiles or their offspring. It is significant to note that the last time Jerusalem is mentioned in the book of Ezekiel is when a messenger announcing its destruction arrives among the exiles in Babylon. The

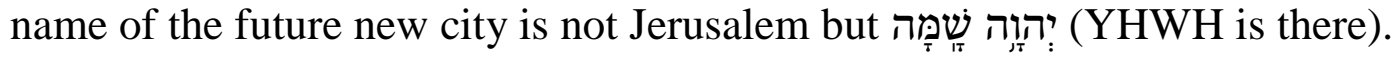

\section{B WHAT ABOUT THE PRESENCE OF YHWH IN BABEL?}

The exilic community and all readers of the book of Ezekiel are warned to distance themselves from Israel's past and to orientate their lives radically to the future promised by YHWH. But can we say anything about the condition of the exiles in Babylon with regard to the relationship of YHWH with them? In Ezek 8-11, we read that the prophet is transported in spirit from the community of Tel Aviv at the river Chebar in Babylon to the temple in Jerusalem. In his second vision, he sees with his own eyes how the glory of YHWH leaves the temple. ${ }^{12}$ The description of the departure is described in four phases or scenes in all. ${ }^{13}$

11 Renz, Rhetorical Function, 70, 165, 178.

12 de Vries, Kābôd, 273. William Tooman, "Ezekiel's Radical Challenge to Inviolability," ZAW 121/4 (2009): 498-514, has argued that the vision of Ezek 8-11 does not depict the abandonment of the temple by the glory of YHWH, but rather a visitation by the glory of YHWH to destroy it. His main point is that the glory of YHWH had already been depicted outside the temple when Ezekiel was called (Ezek 1-3). For the prophet's second vision, the glory of YHWH transports him from Babylon to Jerusalem (Ezek 8:2). I do not find Tooman's arguments conclusive. The fact that the glory of YHWH could manifest itself outside the temple does not mean that it actually resided in it. The final vision, in particular, makes clear that the temple is the place where the glory of YHWH resides on earth. The abandonment described in Ezek 8-11 is reversed. The difference with the former situation is that the glory of YHWH will not leave the temple any more (Ezek 44:1-2).

13 First, the glory of YHWH moves from the cherub(s) above the mercy-seat to the temple threshold (Ezek 9:3). This description is repeated with the remark that the temple was filled with the cloud and its court with the brightness of the glory of YHWH (Ezek 10:4). In the third scene, we read that the glory of YHWH goes up from the threshold of the temple to the vehicle (throne with cherubs as throne-bearers) ready waiting, and stands upon it (Ezek 10:18-19). Finally it is stated that that the glory of YHWH went up from the midst of the city and stood on the mountain that is to the east of the city (Ezek 11:22-23). 
YHWH departs from Jerusalem and its inhabitants, but what about the exiles in Babylon? According to Ezek 9:2, while the prophet is in spirit in the court of the temple, the six men (angelic beings) appear out of the north with a slaughter weapon in their hands. ${ }^{14}$ The prophet also sees a seventh heavenly figure, clothed in linen. ${ }^{15}$ This heavenly scribe is tasked with placing a mark upon those inhabitants of Jerusalem who sigh under the religious, cultic and social injustice of their day. Even before the judgment has been executed, the first phase of the departure of the glory of YHWH is mentioned (Ezek 9:3). When the judgment is executed by the six heavenly figures, the prophet asks in Ezek 9:8b in despair whether even the remnant (שָאֵֵרית) of Israel will be given over to destruction; a question he repeats in Ezek 11:13b. If even the remnant is completely destroyed, the judgment will be completely irreversible. ${ }^{16}$

The answer of YHWH in Ezek 9:9-10 seems to imply that the prophet's fear is well-founded: YHWH says that he will not spare, nor have pity, because guilt of the house of Israel and Judah is exceedingly great. Between the third (Ezek 10:18-19) and the fourth phase (Ezek 11:22-23) of the departure of the glory of YHWH, the prophet for the second time cries out in despair in

14 The north is the direction from which the Assyrian and Babylonian enemies came to the land of Israel from Mesopotamia. Hence, the north is connected with destruction. 15 Linen was characteristic clothing both for priests (Exod 28:29-42) and for heavenly beings (Dan 10:5; 12:6-7). Here, we must think of the figure that does service in the heavenly Temple.

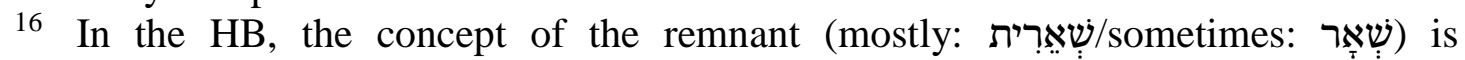
developed in connection with the falling away of the people of Israel from YHWH and his service. The first usage of the term in the HB in its canonical form is found in the

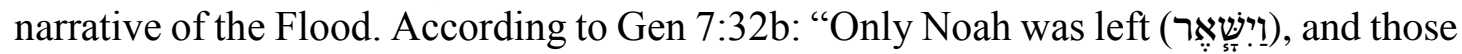
with him in the ark." In the history of Israel as a people in the land of Canaan, we find its earliest expression in the narratives of Elijah. YHWH assures Elijah: "Yet I will leave seven thousand in Israel, all the knees that have not bowed to Baal, and every

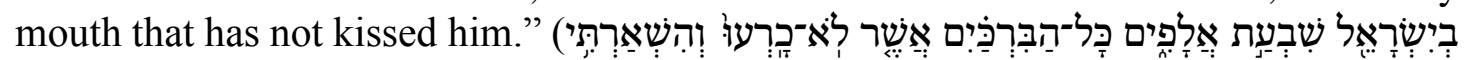

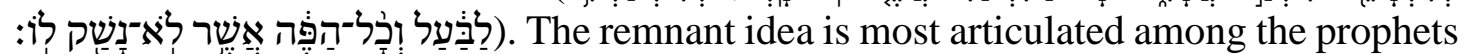
of the eighth century BCE, beginning with Amos. The remnant motive plays a significant role in the book of Isaiah. Jeremiah, who lived during the end of the preexilic period and the beginning of the exilic period, makes the most extensive use of the root שאר. In the book of Jeremiah, the noun שֵֶׁרית usually designates the survivors left behind in Jerusalem by their conquerors. This remnant is insignificant or will be totally destroyed. Hope for the future is connected with the exiles in Babylon. The word ששׁארית can be used of them also (Jer 23:3; 31:7; 50:20). However, Jeremiah seems to prefer the word isiles) when speaking about the positive future of the exiles (Jer $24: 5 ; 28: 4,6 ; 29: 4,16,20)$. 
Ezek 11:13b: "Ah, Lord YHWH, will you make a full end of the remnant of Israel?" In fact, the second cry is more urgent than the first. ${ }^{17}$

Only after this second cry of despair YHWH assures the prophet that this fear is unfounded. YHWH promises not only that he will restore Israel and gather the exiles out of the countries where they have been scattered, but also that he will be a מִקְָּּש מִעַט (temporary or little sanctuary) for the exiles in Babylon (Ezek 11:14ff.). Perhaps it not without significance that the glory of YHWH when departing is seen for the last time by the prophet as it hovers on the mountain that is to the east of Jerusalem (the Mount of Olives) (Ezek 11:23). The glory of YHWH departs in an eastward direction, which is in the direction of Babylon, where the exiles live. So the fourth stage contains the veiled hint of a presence of YHWH among the exiles in Babylon; this provides an indication as

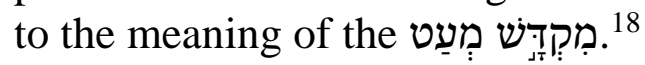

\section{EZEKIEL 11:16: TWO WAYS TO UNDERSTAND THE EXPRESSION מִקְָּּש מְעַט}

In Ezek 11:26, YHWH promises explicitly to the prophet that he will be a מִקְָָּּש מִעַט for the exiles. In the first place, I note that the book of Ezekiel makes great use of older traditional material. In several instances, this must have been material that was also available in written form. ${ }^{19}$ If we can rely upon the MT at Isa 8:14, it therefore seems quite likely that we can hear an allusion to this text of Isaiah in Ezek 11:26. ${ }^{20}$ In the context of the threats posed to Judah by Syria

17 In the first cry, the prophet uses the hip 'il of the verb שָָָׁ (destroy), and in the second the qal of the verb כָָָָּ (completely destroy/make a full end of).

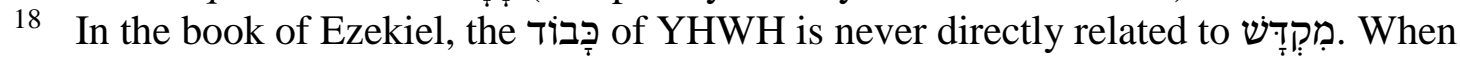

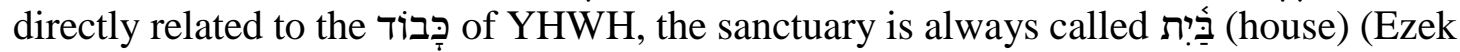
9:3; 10:4, 18, 19; 43:4, 5; 44:4). I do not suggest that the word מִקְָָּ as such suggests a reduced presence, for it is also used when in Ezek 37:26, 28 a new sanctuary is promised. Nevertheless, it remains noteworthy that the word for the new temple is reserved for the final vision in connection with the return of the כָָּּ

19 I shall give two examples in which it is very likely that the prophet had access to written material. The description of the situation on the Day of YHWH in Ezek 7:19 is almost completely comparable to that given in Zeph 1:18. In the portrayal of the spiritual condition of the people of Israel, the book of Ezekiel is congruent with the priestly code of the Pentateuch and particularly with the Holiness Code (Lev 17-26). Especially, there is a close connection between Ezek 4-6 and the curses of the covenant in Lev 26. Both Avi Hurvitz, A Linguistic Study of the Relationship between the Priestly Source and the Book of Ezekiel: A New Approach to an Old Problem, CahRB 20 (Paris: Gabalda, 1982), and Mark F. Rooker, Biblical Hebrew in Transition: The Language of the Book of Ezekiel, JSOTSup 90 (Sheffield: Sheffield University Press, 1990) have shown that the language of the Holiness Code predates the language of the book of Ezekiel.

20 The conjectures מַקְשְִׁיר (snare) or (cause of difficulty) have been suggested. Targum Jonathan has but פוּרָָן (vengeance/avenger). The MT is clearly the harder 
and Northern Israel in the latter half of the eighth century BCE, the prophet assures the inhabitants of Jerusalem that YHWH himself will be for them a sanctuary, a place of refuge. ${ }^{21}$

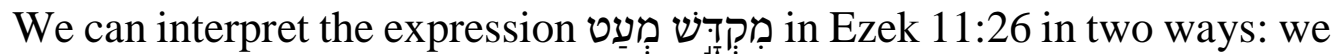
can understand it either temporally (a little while, temporary) or quantitatively (not large). ${ }^{22}$ Perhaps both elements are intended. It is the latter that will have to bear the emphasis: the presence of YHWH and his wiּ with the exiles are small in comparison with his presence in the temple prior to his departure from it. We have to do with a reduced presence of YHWH. Nevertheless, he will be present, and that is a message of hope. Another consideration supporting the hopefulness of the message is that we may also see in מִעט a hint that the exile will not last interminably.

In Ezek 11:16, the place of worship is personalized. If we reject the MT of Isa 8:14, then Ezek 11:16 is the only place in the HB where YHWH himself is said to be a sanctuary. YHWH promises to be for the exiles what the temple had been for them heretofore in Jerusalem. ${ }^{23}$ As long as the כָּב of YHWH resided in the temple, this oracle could not have any real significance; once the prophet has seen in his second vision that the כָּ of YHWH leaves the temple, this oracle is highly significant and a source of hope for the exiles.

reading and makes excellent sense. The LXX agrees with the MT and translates $\dot{\alpha} \gamma i \alpha \sigma \mu \alpha$ but puts a negative before the ensuing parallels. The MT presupposes here that the attitude the inhabitants of Jerusalem take towards YHWH will determine how they experience him.

21 Garry V. Smith, Isaiah 1-39, NAC 15a (Nashville: Broadman \& Holman Academic, 2007), 227, points out the parallel with Ezek 11:16.

22 מִעַ can be a substantive but is also used appositional-adjectivally or adverbially.

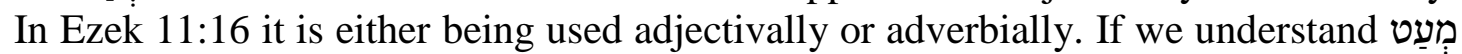

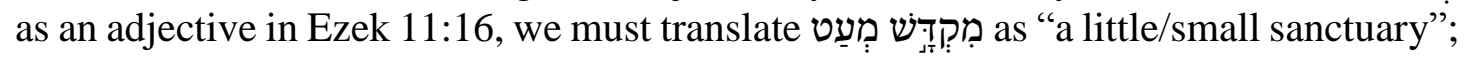

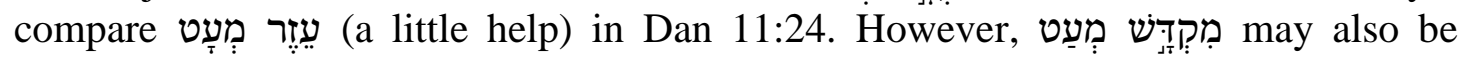
understood adverbially, either temporally "for a little while" - alluding to the limited duration of the exile, or quantitatively - "to a limited extent." The adverbial renderings better suit the context. If we compare leading translations, we can see that several translators have made differing choices here.

Compare the following translations:

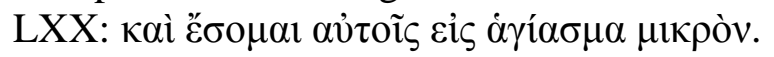

VULGATE: ero eis in sanctificationem modicum.

KJV: yet will I be to them as a little sanctuary.

NIV: yet for a little while I have been a sanctuary for them.

ESV: yet I have been a sanctuary to them for a while.

JPS: and I have become to them a diminished sanctity.

23 We can moreover understand the מִקְָּּש מְעַט, in light of Jer 29:12-14, as being the closeness of YHWH experienced by the exiles in prayer. 
The kernel of the promise of which a מִקְדָּש מְעַט is the harbinger is the covenant formula, which is cited in its full form in Ezek 11:20b: "And they shall

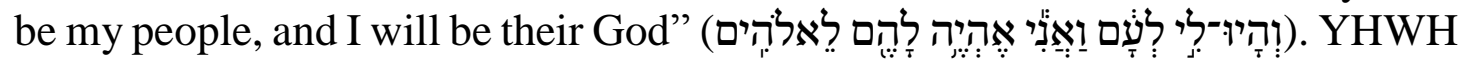
will remain faithful to his covenant with Israel. The exiles can be sure that in accordance with his covenant loyalty, YHWH will reverse the exile (cf. Ezek 16:62). He is loyal to his covenant despite Israel's unfaithfulness. This assurance is already a form of מִקְָּּש מְעַט

\section{HOW YHWH WILL BE A SANCTUARY FOR THE EXILIC COMMUNITY}

How are we to understand the kind of presence that YHWH will have in the

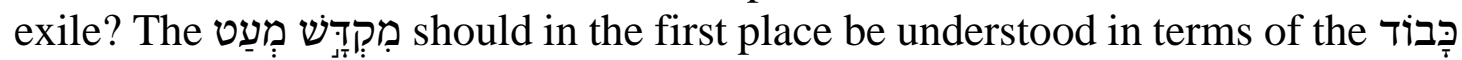
of YHWH, which according to the prophet's calling-vision is well able to appear in Babylon. The calling of Ezekiel is an indication that in some sense the prophet mediates the presence of YHWH in exile (Ezek 1-3). ${ }^{24}$ It is a sign of the fact that YHWH has not completely left the exiles. After the six executioners have done

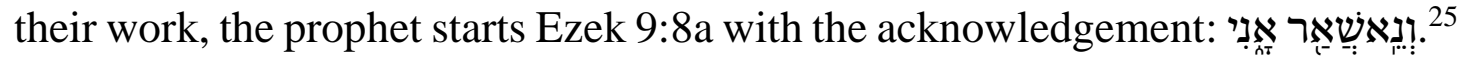
This expression can be understood as "I was left by myself" or "I alone was left." I suggest the second interpretation and see here again an indication that the prophet mediates the presence of YHWH in exile. That impression is reinforced by how the prophet here - unusually - uses the personal pronoun אְִּ of himself.

In the book of Ezekiel, that little word is reserved almost exclusively for YHWH. Of the 169 times that אַנ occurs in Ezekiel, all but nine of the mentions refer to YHWH. Apart from in Ezek 9:8, אִ refers to the prophet in Ezek 1:1;

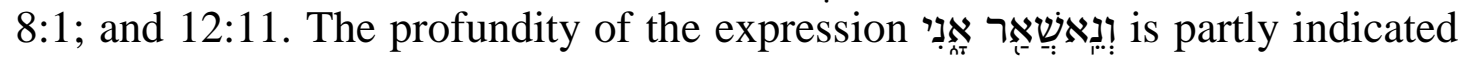
by the fact that this is the only time in the book of Ezekiel that אִנִ is used of the prophet in a verb sentence. The three other sentences where אִּני is used for the prophet are nominal sentences. Noting the correspondence between Ezek 9:8a and Ezek 11:13ff., we can conceive of the little sanctuary as the prophet himself, who has been given to see the כָָּ of YHWH in exile and through whose prophecies of salvation $\mathrm{YHWH}$ is close to the exiles.

Later, we read expressly that the prophet is a sign (מing) for the exiles (Ezek $12: 6,11 ; 24: 24,27)$. He is not only a sign of judgment but also of hope. This hope has to do with the fact that after the fall of Jerusalem, the prophet's

24 In the traditional Jewish exegesis, מִקְדָּש מְעַט is taken to mean the synagogue. We find this interpretation as early as Targum Jonathan. However, there is no proof for that notion: the first indications of the presence of synagogues are several centuries after the exile.

25 The nip 'al of the verb שאר in the first part of Ezek 9:8 has a relationship with the

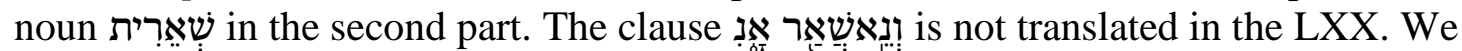
must assume that the words did not feature in the Hebrew manuscript used by the translator of the LXX. 
silence ends (Ezek 24:24, 27; 33:22). From now on, his message is exclusively a message of hope.

\section{E THE SILENCE OF THE PROPHET AND ITS ENDING}

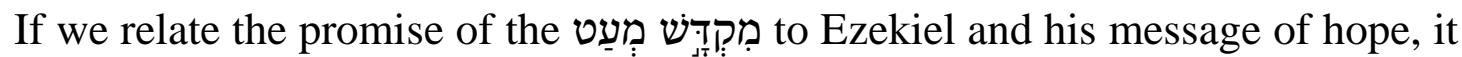
is clear that we must pay attention in this context to his silence beginning seven days after his having been called (Ezek 3:24-27). ${ }^{26}$ It finally ends when he hears the news of the fall of Jerusalem (Ezek 33:22). The passages on the silence of the prophet confront us with some difficulties. Gerhard Fohrer and Walther Zimmerli are of the opinion that the words in 3:24b-27 about the prophet's muteness are secondary and ought to be moved to a place after $24: 26 \mathrm{~b} .{ }^{27}$ These OT scholars believe that these words obtained their placement in 3:24b-27 in order to accentuate the muteness.

Berend Maarsingh believes that there were two distinct periods of muteness: the first when his prophetic work commenced and the second, which lasted 175 days, around the fall of Jerusalem. ${ }^{28}$ According to Ellen F. Davis, Ezekiel's muteness is metaphoric for the trend towards immediately writing down prophetic messages. The prophetic message comes to Ezekiel in the form of a text; the digested scroll (Ezek 2:9ff.) must speak through him. ${ }^{29}$ Nevertheless, if we follow this view, the actual silence of the prophet remains unexplained.

I suggest that Ezekiel's silence means that he remained at home and spoke only to the elders who came to him. We must translate 3:27a iteratively: "every time I address you, I lose your tongue. ${ }^{\prime 30}$ Seven days after his calling, the prophet

26 The period of seven days between the calling of the prophet and his initiation corresponds to the time of separation for those who were being consecrated priests (Lev 8:33ff.). This is an indication that the calling of Ezekiel to prophet hood has the traits of a priestly dedication. Henry L. Ellison, Ezekiel: The Man and His Message (Grand Rapids: Eerdmans, 1956), 29; Thomas J. Betts, Ezekiel the Priest: A Custodian of Tôrâ, StBibLit 74 (New York: Peter Lang, 2005), 47ff. Ezekiel's silence, too, is priestly in character: the priests were expected to be silent as they carried out the sacrificial service. Israel Knohl, The Sanctuary of Silence: The Priestly Torah and the Holiness School (Minneapolis: Fortress Press, 1995).

27 Georg Fohrer, Ezechiel, HAT 13 (Tübingen: Mohr, 1955), 26); Zimmerli, Ezechiel $1-24,106 f f$.

28 Berend Maarsingh, Ezechiël, Vol 1, POuT (Nijkerk: Callenbach, 1985), 1:50.

29 My translation. The ESV has "But when I speak with you, I will open your mouth." Cf. Davis, Swallowing the Scroll, 50ff.

30 Allen, Ezekiel 1-19, 63; Daniel I. Block, The Book of Ezekiel: Chapters 25-48 (Grand Rapids: Eerdmans, 1998), 158; Greenberg, Ezekiel 1-20, 102; De Vries, Kābôd, 258. 
hears that he will not be able to speak but will be dumb. The muteness of the prophet is one of a trio of restrictions relating to his forthcoming actions. ${ }^{31}$

When the prophet opens his mouth before the fall of Jerusalem, it is usually for prophecies of judgments to be declared in each case. Ezekiel is merely the mouthpiece of YHWH. When Ezekiel speaks, YHWH is speaking, and when Ezekiel is silent, YHWH keeps silent. While the prophet is mute, he cannot act as an ${ }^{32}$ The prophet is not given powers to play a mediator's role. ${ }^{33}$ One can only either resist the message of God's judgments or accept them. ${ }^{34}$ The judgments as such are irreversible. Repentance is no longer a possibility, so that YHWH will not carry them out. For Ezekiel's muteness, we find a parallel in Jeremiah, Ezekiel's older contemporary: Jeremiah was not permitted to intercede for the people (Jer 7:16; 11:14; 14:11).

Only once the veracity of his prophecies of doom has been borne out does Ezekiel speak openly and in public (Ezek 24:25-27; 33:21-22). The prophet's

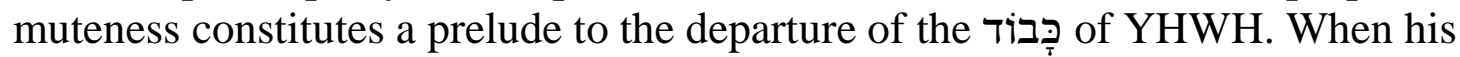
tongue is loosened again, this is a harbinger of the return of the כָברוֹ After Ezek 33 we find no longer a message judgment for Israel, but only a message of hope.

\section{F Tמקדָּש מְעַט AND THE ORACLES OF HOPE IN EZEKIEL 34- 48}

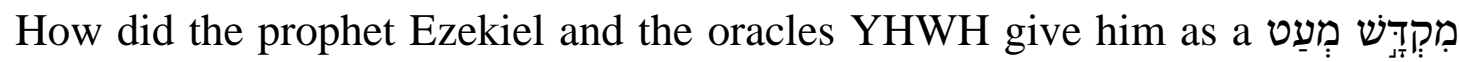
function in exile? I start with the fact that is highly significant here that the call of Ezekiel to prophethood has priestly features. ${ }^{35}$ As a prophet, Ezekiel diagnoses Israel's problem in priestly terms.$^{36} \mathrm{He}$ offers a solution using priestly traditions. The promises made in Ezek 3:18ff., 18:4ff. and 33:1ff. that the just and the repentant will live, have as their background the casuistical, priestly laws.

31 The other two restrictions are that he must remain at home from now on and he must be bound.

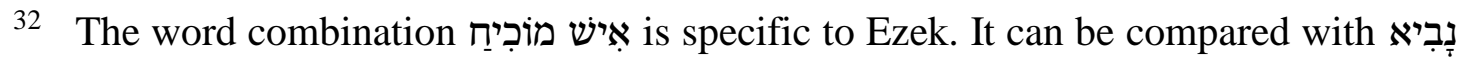
אִ in Judg 6:8.

33 In the wisdom literature, we encounter the מiֹכִיח as the one who punishes and warns in an attempt to improve the behaviour of another (Prov 9:7; 24:15; 25:12; 28:23). In legal trials, the מiֹ מị had a role in the conduct of procedure (Isa 29:1; Amos 5:10). Whether he acted as prosecutor or defendant depended on the context. In Job 9:33, the מוֹכִיח is a man who lays his hands on the shoulders of both parties to attain a right relationship between them.

34 Renz, Rhetorical Function, 159-160; Robert R. Wilson, "An Interpretation of Ezekiel's Dumbness," VT 22/1 (1972): 91-104.

35 Cf. page 12 and especially note 23.

36 Ezekiel uses the words טָמֵא (unclean/defile) and (pollute, defile, profane) to characterize the sins of the people of Israel, and that not only for cultic but also for sexual and social sins. 
Another background that can be understood for the use of language in those passages is the temple liturgy (Pss 15; 118:19-20) sung when the gates of the temple were entered. Ezekiel is promising life to those in exile, just as in Jerusalem the priests did when they sang such promises as they passed inside the gates of the sanctuary. ${ }^{37}$

Already in the first section of Ezekiel, we find here and there a message of hope. ${ }^{38}$ Ezekiel 6 is the hinge: it contains a message of total perdition yet concludes with the cleansing of the prophet himself and with a veiled message of hope and expectation. It is no coincidence that we find the first explicit

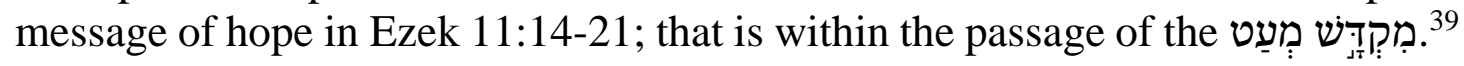

The transition within Ezekiel to a message exclusively of hope we find after Ezek 33. This chapter belongs formally and structurally to the third section of the book of Ezekiel, but it also harks back to Ezek 24 and it is the conclusion of the message of judgment. Before the prophet actually makes the transition to announcing a message of hope, he first declares on the authority of YHWH that there is no hope for the remaining inhabitants of the land of Israel after the fall of Jerusalem (Ezek 33:23-33). Ezekiel 34-48 announces the restoration and glorious future of the people and land of Israel.

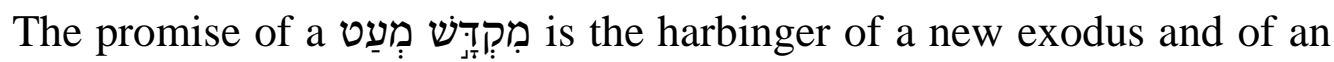
inward transformation (Ezek 11:17ff.); the promise of an inward transformation receives its outworking in the second half of the book of Ezekiel, especially in Ezek 36-37. This transformation opens the way for the return of the כָּב YHWH to a completely new temple that surpasses the old temple in holiness. ${ }^{40}$

37 Walther Zimmerli, The Fiery Throne: The Prophets and Old Testament Theology, ed. Karl C. Hanson (Minneapolis: Fortress Press, 2003), 94; Zimmerli, Ezechiel 1-24, 398.

38 We can divide the book of Ezekiel into either three or two sections, namely Ezek 124; 25-32; and 33-48. In Ezek 25-32, we find the prophecies against the nations. If we divide the book of Ezekiel into two sections, we must reckon them to belong to the second section. The judgment of the nations is an introduction to the message of hope for the nations. In Ezek 28:24-26, we find a message explicitly of hope for Israel. Within Ezek 25-32, there are 97 verses preceding 28:24-26 and another 97 verses after that section (see Block, Ezekiel: Chapters 25-48, 4-5).

39 There are also glimpses of hope in Ezek 16:60-63; 17:22-24 and (if we divide the book of Ezekiel into three sections) in the second part, in Ezek 28:24-26.

40 The tabernacle had only three zones with increasing degrees of holiness. If we assume that the walls around the forecourt of the temple of Solomon and the gates that give access to the innermost court of the temple of Ezekiel demarcate a separate sphere, then the zone count is five and seven respectively. Given the meaning of the number seven, that is the preferable interpretation of the number of the spheres of holiness in the temple of Ezekiel. Much more emphatically than in the tabernacle and the temple of Solomon, the focus is upon gradation and the concomitant separation. Kalinda Rose 
The final vision of Ezekiel, in particular, shows that the mediating function of the prophet has a priestly aspect.

The fulfilment of the final vision will see to it that the exile is definitely a past reality, but in the exile this vision is an essential part of the promise of the מִקְָּּש מְעַט for the exiles. In Ezek 11:15, the prophet repeats the words of the inhabitants of Jerusalem who are left in the land after the destruction of the city

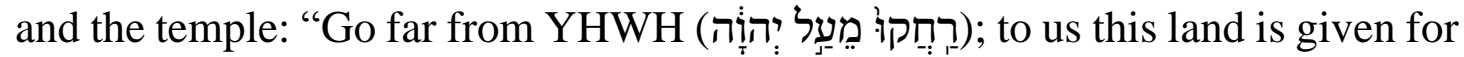
a possession." In Ezek 11:16, YHWH admits that he has distanced the exiles

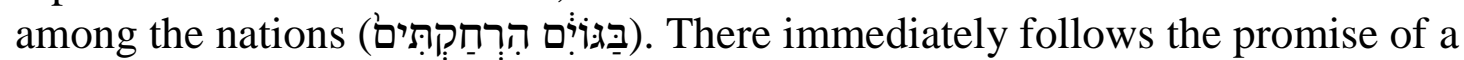

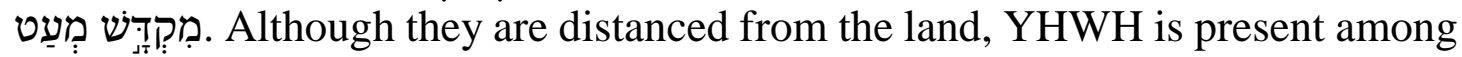

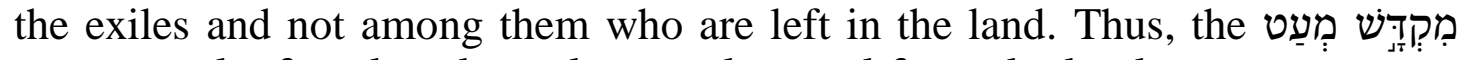
mitigates the fact that the exiles are alienated from the land.

The verb רחק is used for the first time in the book of Ezekiel in Ezek 8:6. By their sins, the people of Israel are driving away, or distancing, YHWH from

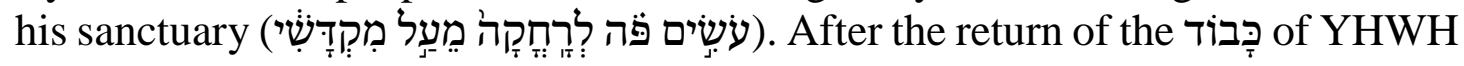
to a completely new temple, the prophet hears YHWH saying to the people of Israel that they will or must put their whoring and the dead bodies of their kings

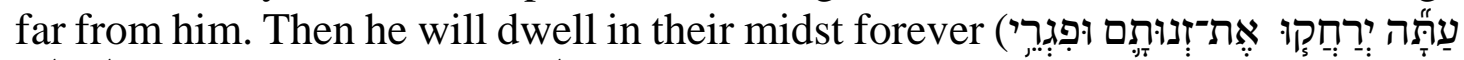

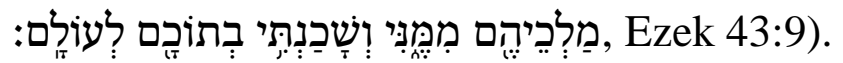

Must we understand יִ ירחְ in Ezek $43: 9$ as a command or an announcement? Almost all translations choose the former option. ${ }^{41}$ In almost

Stevenson, The Vision of Transformation: The Territorial Rhetoric of Ezekiel 40-48, SBLDS 154 (Atlanta: SBL Press, 1996), 117; Jon D. Levenson, Theology of the Program of Restoration of Ezekiel 40-48, HSM 10 (Missoula: Scholars Press, 1976), 16; de Vries, Kābôd, 307-8. In the final vision, when the new temple and its service are described, no high priest is mentioned. The explanation for this cannot be that the legislation in the final vision of Ezekiel predates the priestly legislation of the Pentateuch; the presupposition of such a view is that the priestly legislation of the Pentateuch is the later development of an earlier stage of priestly service in which there was no place for a high priest. In fact, the final vision of Ezekiel presupposes the priestly legislation of the Pentateuch. In the final vision, the holy of holies is so exclusively the

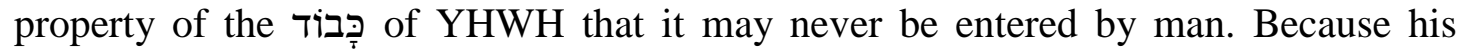
services are no longer required, no high priest has been spoken of throughout the book of Ezekiel. In the temple of Ezekiel, the holy place has only a wooden altar, which is also called a table (Ezek 41:22). It is likely that this wooden altar or table has the function that the table of shewbread had in the tabernacle and the temple of Solomon. It is not impossible that the intention of this inclusion is that the holy place of the new temple will have only a table of shewbread and no incense offering. The fact that the altar is wooden also decreases the likelihood that it is there for incense offerings. This therefore means that the holy place will only be entered on sabbaths for the priests to change the shewbread (cf. Lev 24:8). De Vries, Kābôd, 305-6, 315-16.

41 An exception is the Dutch States Translation (SV, 1637). This is one of the instances where the SV does not follow the KJV (1611). The medieval Jewish exegetes Rasji and 
every instance, a qatal or yiqtol form in the third person after עָתָ can be understood as an imperative mood. Obvious exceptions to this are $1 \mathrm{Kgs}$ 12:26b and Job 16:7. ${ }^{42}$ Following the Vulgate (nunc ergo repellant), I would more readily prefer an indicative mood here. ${ }^{43} \mathrm{My}$ argument is that in the third section of the book Ezekiel, we read almost exclusively about what YHWH does and not about what Israel is commanded to do. ${ }^{44}$ YHWH himself accomplishes among the members of the people of Israel what he expects of them. ${ }^{45}$

By reading or hearing the description given by the prophet of the new temple and its service, the readers and listeners of the book of Ezekiel can imagine what it will be like to participate in its service. They can be sure that the future that is described will one day be a reality. Hence, the description of the new temple and its service has, especially in the exile, the function of a מִקְָָָּּש מִעַטט.

The residing of the כָּב of YHWH in a new and completely pure temple is the final hope of the book of Ezekiel. In the final vision of Ezekiel the new temple is outside the new city. Nevertheless, the name of the new city, which forms the expression that concludes the final vision and the entire book of Ezekiel, is a suitable summary of the final hope which YHWH gives the exile through the oracles of Ezekiel: יהוזנה שָָׁמָה (YHWH is there). This is a powerful

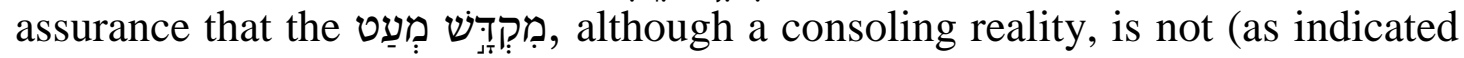
by the word מִעַט) the final reality.

In summary, I restate that there are several indications that the prophetic

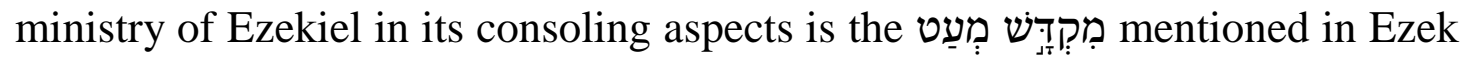
11:16. Firstly, we can consider in this regard his message of life for those who adhere to their righteousness and for the wicked who repent. He functions for them as a kind of priest who assures them of the spiritual presence of YHWH; a reality to be compared with the entry into the sanctuary. Above all, the message

David Kimchi support the view that we must understand יִ ירָח as as a future and not as a jussive.

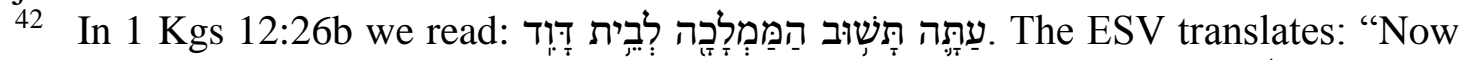

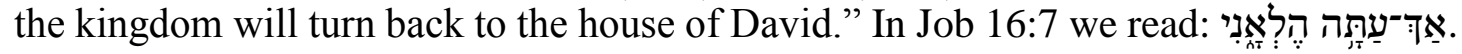
The ESV translates: "Surely now God has worn me out."

43 The LXX has an imperative of the aorist here: $\alpha \pi \omega \sigma \alpha ́ \sigma \theta \omega \sigma \alpha \nu$. However, in Ezek

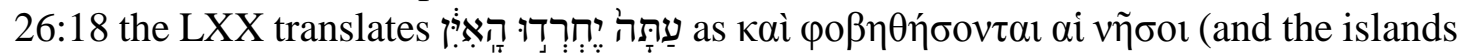
shall be frightened).

44 Now it is true that in Ezek 43:11 we find a condition, namely "if they are ashamed

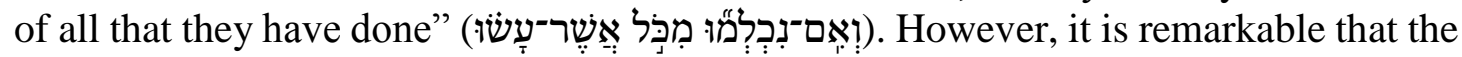

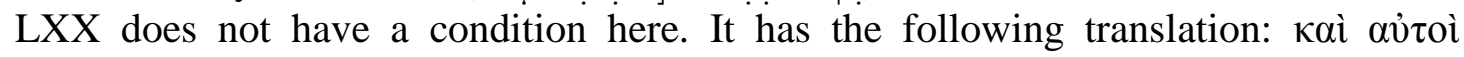

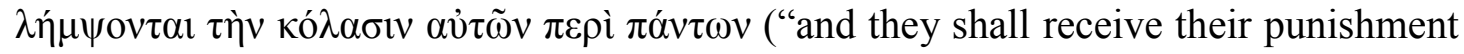
for all they have done").

45 I can cite here the words of St. Augustine: "give what you command and command what you will" (Persev. 20, 53). 
of Ezekiel functions as the מִקְָּּש מִעַט in passages where the glorious future of Israel is foretold and especially in its heralding of the new temple that will surpass the old temple in holiness.

The glorious presence of YHWH among the exiles is a reduced presence compared with the past, but even more so compared with the future. Even the

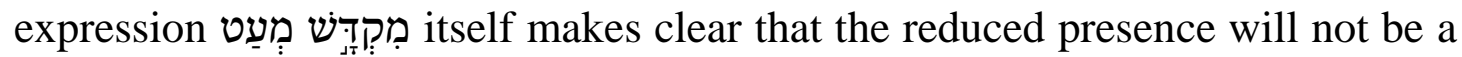

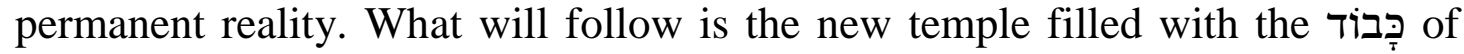
YHWH, who will never leave it again. This latter aspect is symbolized by the fact the east gate of the outer court is closed for ever after the entry of the of YHWH into the new temple (Ezek 44:1-2).

\section{BIBLIOGRAPHY}

Allen, Leslie C. Ezekiel 1-19. WBC 28. Dallas: Word Books, 1994.

Betts, Thomas J. Ezekiel the Priest: A Custodian of Tôrâ. StBibLit 74. New York: Peter Lang, 2005.

Block, Daniel I. The Book of Ezekiel: Chapters 25-48. Grand Rapids: Eerdmans, 1998.

Clements, Ronald E. "Law and Promise." Pages 156-73 in Old Testament Theology: Flowering and Future. Edited by Ben C. Ollenburger. Winona Lake: Eisenbrauns, 2004.

Davis, Ellen F. Swallowing the Scroll: Textuality and the Dynamics of Discourse in Ezekiel's Prophecy. JSOTSup 78. Sheffield: Sheffield University Press, 1989.

de Vries, Pieter. The Kābôd of Yhwh in the Old Testament: With Particular Reference to the Book of Ezekiel. SSN 65. Leiden: Brill, 2015. https://doi.org/10.1163/ 9789004307650

Ellison, Henry L. Ezekiel: The Man and His Message. Grand Rapids: Eerdmans, 1956.

Fohrer, Georg. Ezechiel. HAT 13. Tübingen: Mohr, 1955.

Greenberg, Moshe. Ezekiel 1-20. AB 22. Garden City: Doubleday, 1983.

Hurvitz, Avi. A Linguistic Study of the Relationship between the Priestly Source and the Book of Ezekiel: A New Approach to an Old Problem. CahRB 20. Paris: Gabalda, 1982.

Kitchen, Kenneth A. On the Reliability of the Old Testament. Grand Rapids: Eerdmans, 2003.

Knohl, Israel. The Sanctuary of Silence: The Priestly Torah and the Holiness School. Minneapolis: Fortress Press, 1995.

Levenson, Jon D. Theology of the Program of Restoration of Ezekiel 40-48. HSM 10. Missoula: Scholars Press, 1976.

Lyons, Michael A. From Law to Prophecy: Ezekiel's Use of the Holiness Code. LHBOTS 507. New York: T \& T Clark, 2009.

Maarsingh, Berend. Ezechiël. 2 vols. POuT. Nijkerk: Callenbach, 1985.

Odell, Margaret S. Ezekiel. SHBC. Macon: Smyth \& Helwys Publishing, 2005.

Peels, Eric. "The Assassination of Gedaliah (Jer 40:7-41:18)." Pages 83-104 in Exile and Suffering. Edited by Bob Becking and David Human. OtSt 50. Leiden: Brill, 2009. 
Renz, Thomas. The Rhetorical Function of the Book of Ezekiel. VTSup 76. Leiden: Brill, 1999. https://doi.org/10.1163/9789004276017

Rooker, Mark F. Biblical Hebrew in Transition: The Language of the Book Ezechiel. JSOTSup 90. Sheffield: Sheffield University Press, 1990.

Smith, Garry V. Isaiah 1-39. NAC 15a. Nashville: Broadman \& Holman Academic, 2007.

Stevenson, Kalinda Rose. The Vision of Transformation: The Territorial Rhetoric of Ezekiel 40-48. SBLDS 154. Atlanta: SBL Press, 1996.

Tooman, William. "Ezekiel's Radical Challenge to Inviolability." ZAW 121/4 (2009): 498-514. https://doi.org/10.1515/ZAW.2009.033

Wilson, Robert R. “An Interpretation of Ezekiel's Dumbness.” VT 22/1 (1972): 91104.

Zimmerli, Walther. Ezechiel 1-24. BKAT 13/1. Neukirchen-Vluyn: Neukirchener Verlag, 1996.

Zimmerli, Walther. The Fiery Throne: The Prophets and Old Testament Theology. Edited by Karl C. Hanson. Minneapolis: Fortress Press, 2003.

Dr Pieter de Vries, Theological Faculty of the Free University, De Boelelaan 1105, 1081 HV Amsterdam, The Netherlands. E-mail: dspdevries@solcon.nl or p.de_vries@th.vu.nl. 